\title{
Clinical scale zinc finger nuclease (ZFN)-driven gene-editing of PD-1 in tumor infiltrating lymphocytes (TIL) for the potential treatment of metastatic melanoma
}

\author{
Joal D Beane ${ }^{1 *}$, Gary K Lee ${ }^{2}$, Zhili Zheng ${ }^{1}$, Nimisha Gandhi², Daniel Abate-Daga', Mini Bharathan ${ }^{1}$, Mary Black', \\ Matthew Mendel', Zhiya Yu', Sadik H Kassim', Smita Chandran', Martin Giedlin², Dale Ando², Ed Rebar², \\ Andreas Reik ${ }^{2}$, Michael Holmes ${ }^{2}$, Philip D Gregory ${ }^{2}$, Nicholas P Restifo ${ }^{3}$, Steven A Rosenberg ${ }^{4}$, Richard A Morgan ${ }^{5}$, \\ Steven A Feldman ${ }^{1}$
}

From Society for Immunotherapy of Cancer 29th Annual Meeting

National Harbor, MD, USA. 6-9 November 2014

Multiple inhibitory pathways exist to block the immune response to cancer potentially limiting the effectiveness of adoptive cell transfer (ACT). Programmed cell death-1 (PD-1) is a member of the CD28 superfamily and is expressed on activated T cells. Its ligands, PDL-1 and PDL-2 are expressed on a variety of tumor cells, including melanoma. The binding of PD-1 to PDL- 1 inhibits $\mathrm{T}$ cell effector function, and represents an important mechanism for PDL-1 expressing tumors to evade the host immune response to cancer. PD-1 thus represents an attractive target for gene-editing of tumor-targeted $\mathrm{T}$ cells prior to ACT. To this end, our aim was to eliminate PD-1 expression in tumor infiltrating lymphocytes (TIL) by genome-editing using zinc finger nucleases (ZFNs) directed against the PD-1 gene at a scale sufficient for patient treatment. Using the MaxCyte GT Flow Transfection System to deliver mRNA encoding the PD-1 ZFNs, we show that our clinical scale TIL production process yielded efficient modification of the PD-1 gene locus, with an average modification frequency of $74.8 \%(\mathrm{n}=3$, range $69.9-84.1 \%$ ) of the alleles in a bulk TIL population, which resulted in a 76\% reduction in PD-1 surface-expression. Importantly, the PD-1 gene-edited TIL product displayed an effector memory phenotype and expanded approximately 500 - 2000 fold during a rapid cell expansion in vitro while retaining $\mathrm{T}$ cell effector function. Thus further

'Surgery Branch, National Cancer Institute, National Institutes of Health, Bethesda, MD, USA

Full list of author information is available at the end of the article study to determine the safety of adoptive cell transfer using PD-1 gene-edited TIL for the treatment of metastatic melanoma is warranted.

\begin{abstract}
Authors' details
${ }^{1}$ Surgery Branch, National Cancer Institute, National Institutes of Health, Bethesda, MD, USA. ${ }^{2}$ Sangamo Biosciences, Richmond, CA, USA. ${ }^{3}$ National Cancer Institute, Bethesda, MD, USA. ${ }^{4}$ US National Institutes of Health $(\mathrm{NIH})$, Bethesda, MD, USA. ${ }^{5}$ bluebird bio, Cambridge, MA, USA.
\end{abstract}

Published: 6 November 2014

doi:10.1186/2051-1426-2-S3-P2

Cite this article as: Beane et al:: Clinical scale zinc finger nuclease (ZFN)driven gene-editing of PD-1 in tumor infiltrating lymphocytes (TIL) for the potential treatment of metastatic melanoma. Journal for

ImmunoTherapy of Cancer 2014 2(Suppl 3):P2.

Submit your next manuscript to BioMed Central and take full advantage of:

- Convenient online submission

- Thorough peer review

- No space constraints or color figure charges

- Immediate publication on acceptance

- Inclusion in PubMed, CAS, Scopus and Google Scholar

- Research which is freely available for redistribution 